\title{
ANALISIS PERAN PT. BANK MANDIRI (PERSERO) TBK. UNIT MANDIRI MITRA USAHA DALAM PEMBERIAN KREDIT USAHA RAKYAT PADA USAHA MIKRO DI SAMARINDA.
}

\author{
Umar Hi Salim \\ STIENAS Samarinda \\ Jalan W.R. Soepratman No. 10, Kelurahan Bugis, Samarinda Ulu \\ umarhisalim@gmail.com
}

\begin{abstract}
The purpose of this paper is to identify and analyze the implementation of Uhasa Rakyat Credit from PT. Bank Mandiri (Persero) Tbk. Mandiri Mitra Business Unit in developing micro and small business.

Based on the research, the number of samples taken as many as 65 debtors with the amount of credit $R p$ 20.000.000, - up to Rp 50.000.000, - and indicators to develop small and micro businesses, the debtor (customers), namely; capability of initial capital owned, production activities (business) undertaken, sales turnover obtained, and net profit earned. The result shows that the difference between the average value before and after obtaining credit is 3.97 (12.60 - 8.63), this is quite big. The difference in the average value of this very large, then the debtor who before getting a loan as additional capital to develop business and increase income.

The result of $t$ test analysis for income difference for debtor before and after obtaining credit, where t value counted as $-16,0145$, while t value of table shows 2,000, it shows that $t$ empirical (count) bigger when compared with t table or $-16.0145>2.000$ which means there is a difference of income between the debtor after receiving credit assistance with the debtor who before getting credit assistance from PT. Bank Mandiri (Persero) Tbk. Thus, the proposed hypothesis can be proven and true, that there is a difference between the debtor who after receiving credit assistance with before getting credit assistance.
\end{abstract}

Keywords: Credit Loan, Towards Micro Firms

\section{PENDAHULUAN}

Dalam mengamati sejarah perkembangan ekonomi Indonesia sejak lahirnya Orde Baru hingga kini, pokokpokok pikiran yang mendasari pola perkembangan ekonomi pada masingmasing era tersebut perlu diperhatikan, termasuk kebijakan-kebijakan yarg ditempuh. Pada dasarnya, setiap pemerintahan selalu bertujuan mengembangkan perekonomian sedemikian rupa sehingga taraf hidup bangsa meningkat. Taraf hidup yang lebih baik dicerminkan oleh adanya dua 
kata penting, yaitu masyarakat yang adil (equity) dan makmur (growth). Namun tidaklah mudah mencapai keduanya secara bersama-sama karena pencapaian tujuan yang satu tidak otomatis disertai dengan pencapaian tujuan yang lain.

Pembangunan ekonomi dalam sistem pemerintahan dengan otonomi daerah konsep dasarnya adalah memberikan wewenang kepada daerah untuk merencanakan dan melaksanakan pembangunan daerahnya masingmasing sesuai dengan yang dikehendaki, dan pemerintah pusat akan membantu dan memelihara kegiatan-kegiatan yang tidak mungkin dilaksanakan di daerah, seperti masalah kebijakan moneter, pembangunan jalan antar kota dan provinsi, maupun pemeliharaan sistem pengairan yang melintasi berbagai wilayah.

Untuk itu maka pemerintah daerah dituntut untuk lebih banyak berinovasi dalam bidang administrasi dan ekonomi. Akibat banyak pemerintah daerah yang bersifat otonom, maka banyak pula cara dan sistem administrasi maupun ekonomi yang berbeda-beda yang diterapkan pada daerah. Keberhasilan atau kegagalan rnerupakan suatu inovasi yang nantinya dapat ditiru oleh daerah lain yang juga ingin mendapatkan keberhasilan. Dengan demikian, maka pelaksanaan otonomi daerah harus disesuaikan dengan potensi daerah dan masyarakat masing-masing.

$$
\text { Usaha mikro dan kecil }
$$
memegang peran penting dalam pembangunan ekonomi karena tingkat penyerapan tenaga kerjanya yan relatif tinggi dan kebutuhan modal investasinya yang kecil. Hal ini membuat UMK tidak rentan terhadap berbagai perubahan eksternal sehingga pengembangan pada sektor UMK dapat menunjang pertumbuhan pembangunan ekonomi jangka panjang yang stabil dan berkesinambungan. Rendahnya tingkat investasi dan produktivitas, serta rendahnya pertumbuhan usaha baru di Indonesia perlu memperoleh perhatian yang serius pada masa mendatang dalam rangka mengembangkan Usaha Mikro dan Kecil (UMK) menuju usaha yang berdaya saing tinggi.

Mengingat UMK umumnya berbasis pada sumberdaya ekonomi lokal dan tidak bergantung pada impor, serta hasilnya mampu diekspor karena keunikannya, maka pembangunan UMK diyakini akan memperkuat fondasi perekonomian nasional. Perekonomian Indonesia akan memiliki 
daya saing yang kuat jika UMK telah menjadi pelaku utama yang produktif dan berdaya saing dalam perekonomian nasional. Untuk itu, pembangunan usaha mikro dan kecil perlu menjadi prioritas utama pembangunan ekonomi nasional dalam jangka panjang. Berdasarkan data Kementrian Negara Koperasi dan Usaha Mikro Kecil Menengah menunjukkan bahwa UMK masih menjadi pelaku unit usaha atau 99.99\% dari pelaku bisnis di Indonesia. Usaha Mikro dan Kecil (UMK) di negara berkembang, seperti di Indonesia, sering dikaitkan dengan masalahmasalah ekonomi dan sosial misalnya tingginya tingkat kemiskinan, besarnya jumlah pengangguran, ketimpangan distribusi pendapatan, proses pembangunan yang tidak merata antara daerah perkotaan dan perdesaan, serta masalah urbanisasi. UMK diharapkan dapat memberikan kontribusi yang signifikan terhadap upaya-upaya penanggulangan masalah-masalah tersebut. UMK di Indonesia dapat bertahan di masa krisis ekonomi disebabkan oleh 4 (empat) hal, yaitu:

1. Sebagian UMK menghasilkan barang-barang konsumsi (consumer goods), khususnya yang tidak tahan lama.
2. Mayoritas UMK lebih mengandalkan pada nonbanking financing dalam aspek pendanaan usaha.

3. Pada umumnya UMK melakukan spesialisasi produk yang ketat, dalam arti hanya memproduksi barang atau jasa tertentu saja.

4. Terbentuknya UMK baru sebagai akibat dari banyaknya pemutusan hubungan kerja di sektor formal. UMK di Indonesia mempunyai peranan yang penting sebagai penopang perekonomian.

Berdasarkan pertirnbangan tersebut dan untuk memberikan dasar hukum bagi pemberdayaan usaha kecil maka ditetapkan program Pelaksanaan Penyaluran dan Pengelolaan Program Pinjaman Modal Kredit kepada pelaku usaha kecil dan menegah (UKM) baik perseorangan / individu, Kelompok Usaha Bersama (KUB) maupun Koperasi. Program ini pada akhirnya diharapkan dapat memberikan manfaat berupa peningkatan pendapatan masyarakat yang bergerak di bidang usaha kecil dan menengah.

Modal merupakan faktor masalah yang tidak kalah pentingnya suatu produksi, dimana peranan faktor 
modal lebih menonjol lagi, bila peran perbankan dalam pembangunan ekonomi adalah mengalirkan dana bagi kegiatan ekonomi yaitu salah satunya dalam bentuk perkreditan bagi masyarakat perseorangan atau badan usaha. Bank Mandiri memiliki komitmen untuk membantu mengembangkan Usaha Mikro Kecil dan Menengah (UMKM) serta meningkatkan kesejahteraan masyarakat.

Salah satu bentuk komitment itu adalah dengan dibukanya Kredit untuk Modal usaha bagi UMK dan koperasi yang disebut dengan Kredit Usaha Rakyat (KUR). KUR ini merupakan alternatif bagi Usaha Kecil, Mikro dan

\section{KERANGKA TEORITIS}

\section{Pengertian Manajemen Dana Bank}

Pengertian manajemen dana

bank yang dikemukakan oleh Muchdarsyah Sinungan yaitu: Manajemen Dana Bank adalah siatu proses pengelolaan penghimpunan dana-dana masyarakat ke dalam bank dan pengalokasian dana-dana tersebut bagi kepentingan bank dan masyarakat pada umumnya serta pemupukan secara optimal melalui penggerakan semua sumber daya yang tersedia demi msncapai tingkat
Koperasi untuk mendapatkan modal usaha.

Oleh karena itulah PT. Bank Mandiri (Persero) Tbk Unit Mandiri Mitra Usaha melalui Kredit Usaha Rakyat ini bermaksud memberikan kemudahan akses yang lebih besar bagi para pelaku usaha mikro, kecil, menengah dan koperasi, yang sudah feasibel tetapi belum bankabel mendapatkan modal usaha.

Berdasarkan latar belakang tersebut, maka judul yang diangkat dalam penulisan ini adalah" Analisis Peran PT. Bank Mandiri (Persero) Tbk. Unit Mandiri Mitra Usaha Dalam Pemberian Kredit Usaha Rakyat Kepada Usaha Mikro Di Samarinda". rentabilitas yang memadai sesuai dengan batas ketentuan peraturan yang berlaku. (2002; 79-80)

Sedangkan menurut Faisal Afiff dkk, dalam bukunya strategi dan operasional bank adalah sebagai berikut: Manajemen dana bank adalah suatu pengelolaan penghimpunan dana-dana masyarakat ke dalam bank dan pengalokasian dana-dana tersebut bagi kepentingan bank dan masyarakat pada umumnya serta pemupukan secara optimal melalui penggerakan semua sumber daya yang tersedia demi msncapai 
tingkat rentabilitas yang memadai sesuai dengan batas ketentuan peraturan yang berlaku. $(2002 ; 151)$

\section{Pengertian Bank}

Secara sederhana menurut

Kasmir, menyatakan: "Bank diartikan sebagai lembaga keuangan yang kegiatan usahanya adalah menghimpun dana dari masyarakat dan menyalurkan kembali dana tersebut kemasyarakat serta memberikan jasa-jasa bank lainnya”. (Kasmir, 2007: 2).

Sedangkan menurut UndangUndang Nomor 10 tahun 1998 yang dimaksud dengan bank adalah badan usaha yang menghimpun dana dari masyarakat dalam bentuk simpanan dan menyalurkannya ke masyarakat bentuk kredit dan atau bentuk-bentuk lainnya dalam rangka meningkatkan taraf hidup rakyat banyak. (Kasmir, 2007: 3)

\section{Menurut Undang-Undang} Nomor 10 tahun 1998 (dalam Kasmir, 2005:3) yang dimaksud dengan Bank adalah "Badan usaha yang menghimpun dana dari masyarakat dalam bentuk simpanan dan menyalurkannya ke masyarakat dalam bentuk kredit lainnya dalam rangka meningkatkan taraf hidup rakyat banyak". Sedangkan menurut Hasibuan (2005:2) “Bank adalah lembaga keuangan yang kekayaannya terutama dalam bentuk asset keuangan (financial asset) serta bermotifkan profit dan juga sosial. Bank merupakan pengumpul dana dan penyalur kredit dari dan kepada masyarakat".

\section{Kegiatan Bank}

Menurut Kasmir (2005:29): Kegiatan perbankan yang paling pokok ialah membeli uang dengan cara menghimpun dana dari masyarakat luas. Kemudian menjual uang yang berhasil dihimpun dengan cara menyalurkan kembali kepada masyarakat melalui pemberian pinjaman atau kredit. Di samping itu kegiatan Bank lainnya dalam mendukung kegiatan menghimpun dan menyalurkan dana adalah memberikan jasa lainnya".

Kegiatan pokok bank tersebut yaitu dapat penulis kemukakan sebagai berikut:

a) Menghimpun dana (uang) dari masyarakat dalam bentuk simpanan. Jenis simpanan yang ditawarkan sangat bervariasi tergantung dari bank yang bersangkutan. Secara umum jenis simpanan yang ada di bank adalah terdiri dari simpanan giro (demand deposit), simpanan 
tabungan (saving deposit), dan simpanan deposito (time deposit).

b) Menyalurkan dana ke masyarakat, maksudnya adalah bank memberikan pinjaman kredit kepada masyarakat yang mengajukan permohonan. Dengan kata lain bank memberikan dana bagi masyarakat yang membutuhkan, dan lain-lain.

\section{Pengertian Usaha Mikro dan Kecil}

Menurut Departemen Perindustrian UMK didefinisikan sebagai perusahaan yang dimiliki oleh Warga Negara Indonesia (WNI), memiliki total asset tidak lebih dari Rp 600 juta (diluar area perumahan dan perkebunan). Definisi yang digunakan oleh Biro Pusat Statistik (BPS) lebih mengarah pada skala usaha dan jumlah tenaga kerja yang diserap. Usaha kecil menggunakan kurang dari lima orang karyawan, sedangkan usaha skala menengah menyerap antara 5-19 tenaga kerja. Lain halnya dengan pengertian UMK sesuai dengan Undang- Undang Nomor 20 Tahun 2008 pasal 6 adalah sebagai berikut:

a. Memiliki kekayaan bersih paling banyak Rp 50.000.000,00 (lima puluh juta rupiah) tidak termasuk tanah dan bangunan tempat usaha.

b. Hasil penjualan tahunan paling banyak Rp.300.000.000,00 (tiga ratus juta rupiah).

Menurut Budi Untung (2000), dilihat dari kepentingan perbankan, usaha mikro adalah suatu segmen pasar yang cukup potensial untuk dilayani dalam upaya meningkatkan fungsi intermediasi-nya karena usaha mikro mempunyai karakteristik positif dan unik yang tidak selalu dimiliki oleh usaha non mikro, antara lain:

a. Perputaran usaha (turn over) cukup tinggi, kemampuannya menyerap dana yang mahal dan dalam situasi krisis ekonomi kegiatan usaha masih tetap berjalan bahkan terus berkembang

b. Tidak sensitif terhadap suku bunga

c. Tetap berkembang walau dalam situasi krisis ekonomi dan moneter

d. Pada umumnya berkarakter jujur, ulet, lugu dan dapat menerima bimbingan asal dilakukan dengan pendekatan yang tepat.

\section{Peranan Usaha Mikro dan Kecil}


Dalam menghadapi persaingan yang semakin ketat, karena semakin terbukanya pasar didalam negeri, merupakan ancaman bagi UMK dengan semakin banyaknya barang dan jasa yang masuk dari luar dampak globalisasi. Oleh karena itu pembinaan dan pengembangan UMK saat ini dirasakan semakin mendesak dan sangat strategis untuk mengangkat perekonomian maka kemandirian UMK dapat tercapai dimasa mendatang. Dengan berkembangnya perekonomian rakyat diharapkan dapat meningkatkan pendapatan masyarakat, membuka kesempatan kerja, dan memakmurkan masyarakat secara keseluruhan. Menurut Sjaifudian dkk (2005) Usaha mikro dan kecil menjadi sangat strategis, karena potensinya yang besar dalam menggerakkan kegiatan ekonomi masyarakat, dan sekaligus menjadi tumpuan sumber pendapatan sebagian besar masyarakat menengah kebawah dalam meningkatkan kesejahteraannya. Eksistensi dan peran uasah mikro dan kecil yang pada tahun 2008 mencapai 49,84 juta unit usaha, dan merupakan 99,99\% dari pelaku usaha nasional, dalam tata perekonomian nasional sudah tidak diragukan lagi, dengan melihat kontribusinya dalam penyerapan tenaga kerja, pembentukan Produk Domestik Bruto (PDB) Nasional, nilai ekspor nasional, dan investasi nasional.

\section{Pengertian Nasabah}

Menurut Widjanarto (2003:241) 'Nasabah merupakan orang yang biasa berhubungan dengan atau menjadi pelanggan bank". Sedangkan menurut Kasmir (2005:5) "Nasabah adalah orang atau badan yang mempunyai rekening simpanan atau pinjaman pada bank". Berdasarkan pendapat di atas, dapat penulis simpulkan secara singkat bahwa nasabah adalah orang yang mempunyai rekening baik dalam bentuk simpanan atau menjadi pelanggan bank karena melakukan pinjaman.

\section{Definisi Konsepsional}

Definisi konsepsional ini berfungsi untuk menyederhanakan arti kata atau pemikiran tentang ide-ide, halhal dan kata benda maupun gejala sosial yang digunakan agar orang lain yang membacanya dapat segera memahami maksudnya sesuai dengan keinginan penulis dalam konsep tersebut. Definisi konsep adalah batasan-batasan yang diberikan dalam penelitian yang 
didasarkan pada pengertian para ahli. Berdasarkan judul dan variabel penelitian, maka batasan konsep yang penulis berikan dalam penelitian ini yaitu sebagai berikut:

UKM (Usaha Kecil dan Menengah) "adalah usaha kecil dan menengah yang dilaksanakan secara individu atau orang-pereorang dengan melandaskan kegiatan kewirausahaan berdasarkan dana pinjamannya yang dimanfaatkan”. (Anonim, $2001: 2$ )

\section{Hipotesis}

Hipotesis merupakan kesimpulan sementara terhadap variabel yang diteliti. Berdasarkan teori di atas menggambarkan bahwa adanya satu variable bebas yang saling membedakan, oleh karena itu perlu dilakukan suatu pembuktian hipotesis untuk melihat perbedaan variabel dengan instrument berbeda. Maka hipotesis yang diajukan dalam penelitian ini adalah sebagai berikut:

"Diduga bahwa terdapat perbedaan yang besar antara debitur sebelum dan sesudah memperoleh kredit usaha pada PT. Bank Mandiri (Persero) Tbk. Unit Mandiri Mitra Usaha melalui Kredit Usaha Rakyat di Samarinda.”.

\section{METODE PENELITIAN}

\section{Jenis Penelitian dan Definisi Operasional}

Penelitian ini bermaksud untuk menjelaskan kedudukan variablevariabel yang diteliti serta hubungannya antara satu variable dengan variable lainnya. Penelitian ini bersifat studi kasus.

Dalam definisi operasional adalah gambaran konkrit tentang variabel-variabel penelitian yang diaplikasikan pada situasi nyata di lapangan. Dalam hal ini definisi operasional tentang Peran PT. Bank Mandiri (Persero) Tbk. Unit Mandiri Mitra Usaha melalui Kredit Usaha Rakyat di Samarinda.

PT. Bank Mandiri (Persero) Tbk Samarinda. adalah perusahaan yang bergerak dibidang pelayanan jasa simpanan dan penyaluran dana kembali kepada masyarakat dalam bentuk kredit serta jasa lain yang bekaitan dengan transaksi keuangan.

Modal Usaha Merupakan kemampuan finansial Usaha Mikro Kecil (UMK) dalam menjalankan operasional usahanya,atau untuk memproduksi barang dan atau jasa. 
Satuan untuk mengukur modal usaha berdasarkan nominal uang dalam rupiah.

UKM yang dimaksudkan disini adalah Usaha/Pengusaha Kecil dan Menengah yang merupakan orang secara individu atau berkelompok dalam melakukan kegiatan ekonomi yang dapat menghasilkan.

Produksi; Produksi diartikan sebgai penggunaan atau pemanfaatan sumber daya yang sama sekali berbeda, baik pengertian apa, dan dimana komoditi-komoditi tersebut dialokasikan, maupun dalam pengertian apa apa yang dapat dikerjakan oleh konsumen dengan komodoti itu.

Omzet Penjualan; Omzet penjualan adalah keseluruhan jumlah penjualan barang/jasa dalam kurun waktu tertentu, yang dihitung berdasarkan jumlah uang yang diperoleh dari hasil penjualan yang dilakukan.

Keuntungan; Keuntungan dapat diketahui dengan cara menghitung total penjualan dikurangi total biaya produksi. Satuan untuk mengukur keuntungan tersebut ditetapkan dalam bentuk nominal rupiah dalam setiap bulannya.

Menurut Pindyck ( 1999 ) keuntungan merupakan selisih antara total penghasilan / revenue dan total biaya $/$ cost atau $=\mathrm{TR}-\mathrm{TC}$.

\section{Populasi dan Sampel}

Populasi dari pada penelitian ini adalah sejumlah debitur nasabah yang memiliki rekening pada PT. Bank Mandiri (Persero) Tbk di Samarinda. Pengambilan sampel dilakukan sampling acak, dan yang menjadi responden adalah debitur yang mempunyai jumlah pinjaman $\mathrm{Rp}$ 20.000.000,- sampai dengan Rp 50.000.000,-. debitur kelompok ini banyak yang berhasil mengembangkan usaha di bidang yang mereka jalani.

\section{Teknik Pengumpulan Data}

Dalam penelitian ini pengumpulan data dilakukan dengan mempergunakan cara- cara sebagai berikut:

1. Penelitian Lapangan (Field Work Research) adalah dengan mengadakan penelitian langsung yaitu:

a. Observasi (Pengamatan) yaitu dengan melihat langsung kegiatan yang dilakukan baik karyawan maupun pimpinan.

b. Interview (wawancara) yaitu dengan melakukan wawancara 
secara langsung dengan

pimpinan perusahaan atau staf karyawan untuk mendapatkan data dan informasi mengenai objek yang di teliti.

c. Questioner, mengedarkan daftar pertanyaan kepada mereka yang terkena sampel.

2. Penelitian Kepustakaan (Library Research) yaitu dengan membaca buku-buku literature, laporan laporan, surat kabar dan sumber data sekunder yang ada hubungannya dengan masalah yang di teliti dalam penulisan ini.

Penelitian ini merupakan studi kasus di PT. Bank Mandiri (Persero) Tbk. Unit Mandiri Mitra Usaha. Pengumpulan data dalam penelitian ini dimaksudkan untuk memperoleh sumber informasi yang relevan dan akurat. Data yang digunakan dalam penelitian ini adalah data primer dan data sekunder. Untuk mendukung penelitian diperlukan data yang aktual. Berdasarkan sumbernya, data-data yang diperoleh dibedakan menjadi:

Data primer yang dikumpulkan dalam penelitian ini adalah data yang diperoleh secara langsung dengan memberikan kuesioner atau daftar pertanyaan kepada pengusaha mikro dan kecil di Samarinda yang melakukan pinjaman KUR kepada PT. Bank Mandiri (Persero) Tbk. Unit Mandiri Mitra Usaha. Kuesioner atau daftar pertanyaan yang diajukan disusun berdasarkan variabel yang diteliti dengan menyediakan jawaban alternatif yang dipilih oleh responden sesuai dengan kondisi riil atas persepsi, pendapat dan opini tersebut, sehingga diharapkan didapat data yang akurat atas penelitian ini.

Data Sekunder; Data ini dapat dipero leh dari dokumen dan laporan tahunan yang diperlukan dalam penelitian ini di PT. Bank Mandiri (Persero) Tbk. Unit Mandiri Mitra Usaha, sumber literatur, internet, dokumentasi dan data pendukung lainnya.

\section{Instrumen Penelitian}

Karena pada prinsipnya meneliti adalah melakukan pengukuran, maka harus ada alat ukur yang baik. Alat ukur dalam penelitian biasa dinamakan instrumen penelitian. Jadi instrumen penelitian adalah suatu alat yang digunakan mengukur fenomena atau variabel penelitian. 
Untuk mengetahui besarnya pengaruh variabel di atas, maka dikumpulkan data-data dari lapangan dengan cara menyebarkan kuisioner atau pertanyaan yang berhubungan dengan variabel penelitian ini dan kemudian diolah dengan menggunakan kreteria atau Skala Likert sebagai berikut :

1. Sangat baik : diberi skor 4

2. Baik : diberi skor 3

3. Cukup baik : diberi skor 2

4. Sangat tidak baik : diberi skor 1

\section{ANALISIS DAN PEMBAHASAN}

\section{Analisis}

Nasabah Bank Mandiri terdiri dari berbagai segmen merupakan penggerak utama perekonomian Indonesia. Berdasarkan sektor usaha, nasabah Bank Mandiri bergerak di bidang usaha yang sangat beragam sebagai bagian dari upaya penerapan "Prudential Banking" dan "Best Practices Risk Management' Bank Mandiri telah melakukan berbagai perubahan. Salah satunya, persetujuan kredit dan pengawasan dilaksanakan dengan 'four -eye principle' dimana persetujuan kredit dipisahklan dari kegiatan pemasaran

\section{Teknis Analisis Data}

Data yang diperoleh dari lapangan akan dianalisis dan diuji kebenarannya dengan menggunakan uji t yang bertujuan untuk dapat membuktikan apakah hipotesis dapat diterima atau tidak.

\section{Alat Analisis}

Alat analisis yang digunakan dalam pemecahan masalah sebelumnya adalah statistik dengan model simpangan baku dan rata-rata hitung.

dan business unit. Sebagai bagian diversifikasi risiko dan pendapatan.

Berdasarkan permasalahan yang penulis tetapkan, maka akan disajikan data yang berkaitan dengan masalah tersebut. Adapun data yang disajikan tersebut adalah hasil kuisioner dari debitur terlampir.

Untuk mengetahui perbedaan yang lebih jelas antara kedua variable bebas tersebut di atas dapat di lihat pada bagian analisis dan pembahasan yaitu dengan cara melakukan uji analisis terhadap data

yang diperoleh di lapangan selama penelitian. Oleh karena itu alat analisis yang digunakan adalah statistik model rata-rata hitung, varians dan simpangan baku, 
kemudian dibuktikan dengan uji $t$ yang akan dibandingkan dengan $t$ tabel.

Tabel 4.1 :Daftar Pengelompokan Sebelum dan Sesudah Pinjaman Pada Para Debitur atau Nasabah PT. Bank Mandiri (Persero) Tbk.

\begin{tabular}{|c|c|c|c|c|c|}
\hline $\mathrm{NO}$ & Belum & Meminjam Modal & $\mathrm{NO}$ & Setelah N & eminjam Modal \\
\hline 1 & Nilai & $6=6$ orang & 1 & Nilai 10 & $=6$ orang \\
\hline 2 & Nilai & $7=9$ orang & 2 & Nilai 11 & $=9$ orang \\
\hline 3 & Nilai & $=13$ orang & 3 & Nilai 12 & $=12$ orang \\
\hline 4 & Nilai & $9=20$ orang & 4 & Nilai 13 & $=19$ orang \\
\hline 5 & Nilai & $10=12$ orang & 5 & Nilai 14 & $=16$ orang \\
\hline 6 & Nilai & $11=3$ orang & 6 & Nilai 15 & $=3$ orang \\
\hline 7 & Nilai & $12=1$ orang & & & \\
\hline \multirow[t]{2}{*}{8} & Nilai & $13=1$ orang & & & \\
\hline & Jumlal & $=65$ orang & & Jumlah & $=65$ orang \\
\hline
\end{tabular}

Sumber : Debitur PT. Bank Mandiri (Persero) Tbk. (data diolah)

Berdasarkan nilai pada tabel 5 telah menunjukkan bahwa dari 65 responden yang sebelum menerima pinjaman (kredit) dari bank mandiri dengan menjawab pertanyaan yang terperinci yaitu ada 6 debitur memberikan jawaban dengan jumlah skor 6 poin atau 9,20\%; 9 debitur memberikan jawaban dengan jumlah skor 7 poin atau $13,8 \%$; 13 debitur memberikan jawaban dengan jumlah skor 8 poin atau 20,0\%; 20 debitur memberikan jawaban dengan jumlah skor 9 poin atau 30,8\%; 12 debitur memberikan jawaban dengan jumlah skor 10 poin atau $18,5 \% ; 3$ debitur memberikan jawaban dengan jumlah skor 11 poin atau 4,6\%; 1 debitur memberikan jawaban dengan jumlah skor 12 poin atau $1,5 \%$; dan 1 debitur memberikan jawaban dengan jumlah skor 13 poin atau $1,5 \%$, dan terbagi menjadi 8 kelas interval. Sedangkan dari 65 reponden tersebut yang setelah menerima bantuan kredit dari bank mandiri dengan 
menjawab pertanyaan dan dengan jumlah skor 15 poin atau dikelompokkan menjadi 6 kelas $4,6 \%$.

interval yang terperinci yaitu; ada 6 debitur memberikan jawaban dengan jumlah skor 10 poin atau $9,2 \% ; 9$ debitur memberikan jawaban dengan jumlah skor 11 poin atau $13,8 \% ; 12$ debitur memberikan jawaban dengan jumlah skor 12 poin atau $18,5 \% ; 19$ debitur memberikan jawaban dengan jumlah skor 13 poin atau $29,2 \% ; 16$ debitur memberikan jawaban dengan jumlah skor 14 poin atau 24,6\%; dan 3 debitur memberikan jawaban

Adapun rumus dari alat $\mathrm{Uji}-$ t yang penulis gunakan adalah sebagai berikut:

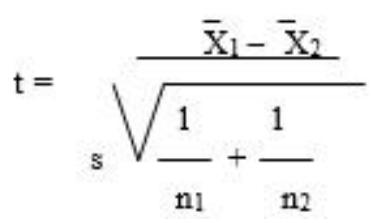

Selanjutnya sebelum data dihitung berdasarkan rumus $\mathrm{Uji}-\mathrm{t}$, maka data yang ada dimaksukkan ke dalam tabel yang dimaksud adalah sebagai berikut :

\begin{tabular}{lllllllll}
\hline X1 & X2 & S12 & S22 & S1 & S2 & S & t & db \\
\hline 8.63 & 12.60 & 2.237 & 1.87 & 1.496 & 1.3675 & 1.433 & -16 & 64
\end{tabular}

Sumber: Diolah Peneliti

Jadi derajat bebas 64 dengan taraf signifikan $5 \%$ dengan ketentuan $t$ tabel $1-1 / 2 \propto, \mathrm{dk} 64=2,000$. Dengan demikian $\mathrm{t}$ hitung adalah -16,0145, sedangkan $\mathrm{t}$ tabel adalah 2,000.

Jadi $\mathrm{t}$ hitung $>\mathrm{t}$ tabel atau $16,0145>2,000$ dengan demikian Ha diterima dan Ho ditolak .

\section{Pembahasan}

Untuk melihat kegiatan usaha kercil dan mikro dapat diketahui bahwa banyak faktor yang dapat mempengaruhi keberhasilan, baik faktor intern maupun faktor ekstern. Faktor
Intern merupakan faktor yang terdapat pada diri individu itu sendiri baik kemampuan intelgensi yang dimilikinya, minat maupun motivasi. Sedangkan faktor extern yaitu faktor yang berasal dari luar individu seperti lingkungan keluarga, linkungan pergaulan, dan masyarakat.

Kegiatan proses untuk mengembangkan usaha kecil dan mikro, dimana para nasabah dengan menggunakan berbagai indikator yaitu dengan kemampuan modal awal yang dimiliki, kegiatan produksi yang dilakukan, omset penjualan yang 
diperoleh, serta keuntungan bersih yang diperoleh.

Berdasarkan data yang penulis kemukakan pada awal bab ini dapat diketahui bahwa pendapatan para usaha kecil dan mikro mengalami sebelum memperoleh pinjaman modal untuk pengembangan usaha dengan jumlah nasabah sebanyak 65 orang, yaitu dari indikator kemampuan modal dengan jawaban 150 atau (150/561 x100\%) 26,74\%; dari indikator kemampuan berproduksi dengan jawaban nasabah 148 atau (148/561 x100\%) 26,38\%; dari indikator omset penjualan yang diperoleh dengan jawaban nasabah 134 atau $(134 / 561 \times 100 \%) 23,89 \%$; serta dari indikator keuntungan bersih yang diperoleh dengan jawaban nasabah 129 atau (129/561 x100\%) 23,00\%.

Sedangkan setelah debitur menerima bantuan kredit (modal pinjaman) dari bank mandiri, maka tingkat pengembangan usaha kecil dan mikro dari 65 debitur dengan indikator kemampuan modal dengan jawaban 210 atau $(210 / 819 \times 100 \%) 25,64 \%$; dari indikator kemampuan berproduksi dengan jawaban nasabah 202 atau $(202 / 819 \quad \mathrm{x} 100 \%) \quad 24,66 \%$; dari indikator omset penjualan yang diperoleh dengan jawaban nasabah 211 atau $(211 / 819 \times 100 \%) 25,76 \%$; serta dari indikator keuntungan bersih yang diperoleh dengan jawaban nasabah 196 atau $(196 / 819 \times 100 \%) 23,93 \%$.

Selisih perbedaan nilai rata-rata sebelum dan sesuada memperoleh kredit sebesar 3,97 $(12,60-8,63)$, hal ini tergolong sangat besar. Perbedaan nilai rata-rata yang sangat besar ini, maka debitur yang sebelum mendapat pinjaman sebagai tambahan modal untuk mengembangkan usaha maupun meningkatkan penghasilan, untuk itu perlu menambah modal untuk usaha tersebut agar penghasilan debitur meningkat.

Keadaan tersebut dapat terjadi karena debitur sebelum memperoleh kredit maka penghasilan masih rendah dibanding dengan debitur setelah memperoleh kredit. Hal ini terlihat dari perhitungan varians yaitu sebelum dengan nilai 2,237 dan sesudah dengan nilai 1,869 , sedangkan niali simpangan baku sebelum sebesar 1,496 dan sesudah sebesar 1,367, ini menunjukkan penyimpangan sebelum lebih besar dari sesudah. Hal lain dilihat dari nilai jarak antara skor jawaban tertinggi dengan terendah, baik sebelum sebesar 7 poin dan sesudah sebesar 5 . 
Berdasarkan hasil analisis uji $\mathrm{t}$ untuk perbedaan penghasilan bagi para debitur sebelum dan sesudah memperoleh kredit, dimana nilai $\mathrm{t}$ hitung menunjukkan sebesar -16,0145, sementara nilai $\mathrm{t}$ tabel menunjukkan sebesar 2,000, hal tersebut menunjukkan bahwa $\mathrm{t}$ empiris (hitung) lebih besar bila dibandingkan dengan $\mathrm{t}$ tabel atau $-16,0145>2.000$ yang berarti terdapat perbedaan penghasilan antara debitur yang sesudah mendapat bantuan kredit dengan debitur yang sebelum mendapat bantuan kredit dari PT. Bank Mandiri (Persero) Tbk.

Dengan demikian hipotesis yang diajukan dapat terbukti dan benar, bahwa terdapat perbedaan antara debitur yang setelah mendapat bantuan kredit dengan sebelum mendapat bantuan kredit.

\section{KESIMPULAN DAN SARAN}

\section{Kesimpulan}

Berdasarkan hasil penelitian analisis yang telah penulis kemukakan pada bab terdahulu, baik mengenai kedua sampel, maka sampailah penulis pada beberapa simpulan sebagai berikut :

1. Berdasarkan penelitian maka jumlah sampel yang diambil sebanyak 65 debitur dengan jumlah kredit Rp 20.000.000,sampai dengan Rp 50.000.000,dan indikator mengembangkan usaha kecil dan mikro, para debitur (nasabah) yaitu; kemampuan modal awal yang dimiliki, kegiatan produksi (usaha) yang dilakukan, omset penjualan yang diperoleh, serta keuntungan bersih yang diperoleh.

2. Hasil perhitungan menunjukkan selisih perbedaan nilai rata-rata sebelum dan sesudah memperoleh kredit sebesar 3,97 $(12,60-8,63)$, hal ini tergolong sangat besar. Perbedaan nilai rata-rata yang sangat besar ini, maka debitur yang sebelum mendapat pinjaman sebagai tambahan modal untuk mengembangkan usaha maupun meningkatkan penghasilan.

3. Debitur sebelum memperoleh kredit penghasilan yang dicapai masih rendah dibanding dengan debitur setelah memperoleh kredit. Ini terlihat dari perhitungan varians yaitu sebelum dengan nilai 2,237 dan sesudah dengan nilai 1,869 , 
sedangkan nilai simpangan baku sebelum sebesar 1,496 dan sesudah sebesar 1,367, ini menunjukkan penyimpangan sebelum lebih besar dari sesudah. Hal lain dilihat dari nilai jarak antara skor jawaban tertinggi dengan terendah, baik sebelum sebesar 7 poin dan sesudah sebesar 5 .

4. Hasil analisis uji $t$ untuk perbedaan penghasilan bagi para debitur sebelum dan sesudah memperoleh kredit, dimana nilai $t$ hitung menunjukkan sebesar $-16,0145$, sementara nilai $t$ tabel menunjukkan sebesar 2,000, hal tersebut menunjukkan bahwa $\mathrm{t}$ empiris (hitung) lebih besar bila dibandingkan dengan $t$ tabel atau $-16,0145>2.000$ yang berarti terdapat perbedaan penghasilan antara debitur yang sesudah mendapat bantuan kredit dengan debitur yang sebelum mendapat bantuan kredit dari PT. Bank Mandiri (Persero) Tbk di Samarinda. Dengan demikian hipotesis yang diajukan dapat terbukti dan benar, bahwa terdapat perbedaan antara debitur yang setelah mendapat bantuan kredit dengan sebelum mendapat bantuan kredit.

\section{Saran}

Adapun saran-saran yang penulis kemukakan adalah sebagai berikut:

1. Perbedaan nilai rata-rata yang sangat besar ini menjadikan suatu ukuran penghasilan bagi debitur yang sebelum memperoleh kredit maupun sesudah memperoleh kredit, agar tetap meningkatkan usahanya.

2. Kepada debitur yang telah memperoleh kredit sebagai modal usaha tetap mempertahankan maupun meningkatkan usahanya agar penghasilannya bertambah.

3. Kepada PT. Bank Mandiri (Persero) Tbk. Unit Mandiri Mitra Usaha terutama Unit Usaha Rakyat diharapkan tetap memberikan perannya kepada debitur yang memiliki niat baik untuk mengembangkan usahanya khususnya Kota 
Samarinda dan Kalimantan

Timur pada umumnya.

\section{DAFTAR PUSTAKA}

Anonim, 2001, Keputusan Menteri Negara Urusan Koperasi dan Usaha Kecil dan Menengah No:70/Kep/Meneg/XII/2001

Tentang Kedudukan, Tugas Pokok, Fungsi, Susunan Organisasi dan Tata Kerja Sta fMeneg Koperasi dan UKM.

Budi Untung, 2000. Kredit Perbankan di Andi :Yogyakarta.. Indonesia.Penerbit

Faisal, Afiff, dkk. 2002. Strategi Dan Operasional Bank, Cetakan Pertama. Penerbit PT. Eresco: Bandung.

Hasibuan, Malayu. 2005. Dasar-dasar Perbankan. Bumi Aksara:Jakarta.

IAI. 2004. Standar Akuntansi Indonesia (SAK). Salemba Empat: Jakarta.

Kasmir. 2005. Bank Dan Lembaga Keuangan Lainnya. PT Raja Grafindo Persada: Jakarta.

\section{_ 2007. Manajemen Perbankan. PT Raja Grafindo Persada: Jakarta.}
Mariam Darus Badrulzaman, Sutan Remy Sjahdeini, Heru Soepraptomo, Faturrahman

Djamil, Taryana Soenandar. 2001. Kompilasi Hukum Perikatan. PT. Citra Aditya Bakti: Bandung.
O.P Simorangkir. 2005. Seluk Beluk Bank Komersial, Cetakan ke-5. Aksara Persada Indonesia: Jakarta. Partomo dan Soejodono. 2004,. Ekonomi Skala Kecil Menengah dan Koperasi. Ghalia Indonesia.: Bogor.

Martono. 2002. Prosiding Seminar Alasional Peranan Strategis Irdustri Kecil dalain Pembangunan Jangka Pandang Tahap II. UKI-Press: Jakarta.

Sjaifudian, Hetifah, Dedi Haryadi dan Maspiyati. 2005. Strategi dan Agenda Pengembangan Usaha Kecil. AKATTGA: Bandung.

Ruddy, Tri Santoso. 2000. Prinsip dasar Akuntansi Perbankan, Cetakan Kedua. Andi Offset:Yogyakarta.

Sinungan, Muchdarsyah. 2002. Manajemen Dana Bank, Edisi Keempat. Bumi Aksara: Jakarta.

Sudjana. 2001. Metode Statistik, Edisi Keenam, Cetakan Kesepuluh. Erlangga: Jakarta.

Widjanarto. 2003. Hukum dan Ketentuan Perbankan Di Indonesia. Pustaka Utama Grafiti: Jakarta.

\begin{tabular}{|c|c|}
\hline $\begin{array}{c}\text { Undang-Undang Nomor } \\
1998 \text { tentang }\end{array}$ & $\begin{array}{l}10 \text { tahun } \\
\text { Perubahan }\end{array}$ \\
\hline $\begin{array}{l}\text { Undang-undang } \\
\text { tahun } 2001 .\end{array}$ & Nomor \\
\hline
\end{tabular}

